\title{
Character Index of Mathematics and Science Student Teachers in Online Learning
}

\author{
Parmin $^{1^{*}}$, Iwan Junaedi'², Eling Purwantoyo ${ }^{3}$, Ibnul Mubarak ${ }^{4}$, Mukhammad \\ Toni ${ }^{1}$, Fiffit Fitrian ${ }^{5}$ \\ 1,2,3,4,5 Faculty of Mathematics and Natural Sciences, Universitas Negeri Semarang, Semarang, Indonesia \\ e-mail: @email.com
}

\begin{abstract}
Online learning changes learning habits from face to face to distance learning. The purpose of the study is to measure the character index of mathematics and science student teachers in online learning during the COVID-19 pandemic. The study used mixed methods, collecting and analyzing quantitative data through questionnaires targeting Mathematics and Science student teachers, followed by qualitative data through interviews. The questionnaire used a Likert five scale option. The number of research targets was 340 student teachers with 224 women and 116 men. The results obtained are four indicators of mathematics and science student teachers characters in online learning that are less than optimal, consisting of beginning and ending lectures by praying, attendance, and politeness while optimal in the timeliness indicator collecting assignments with an index of 4.40 from a maximum index of 5.00. The study concludes that online learning has an impact on the character index of student teachers.
\end{abstract}

Keywords: Character Index, Student Teachers, Online Learning, COVID-19

\section{Introduction}

Issues regarding the character of Mathematics and Science student teachers are discovered through daily observations during activities on campus recommending the importance of giving special treatment to the character formation of student teachers during the COVID-19 pandemic. The polite attitude towards campus residents in educational activities in a normal situation is still not in line with expectations, especially during the pandemic. A pandemic situation is the effect of the COVID-19 outbreak that has led to online lectures. Students in an atmosphere of anxiety and fear of the plague, while the lecture process must continue. This situation has the potential to create psychological pressure, which impacts the implementation of online lectures, which weakens the character-building habit, especially for student teachers. Yin, (2019) and Fukkink et al., (2019) stated that each student teacher is not only required to have scientific competence but readiness to facilitate learning that is oriented towards educating. Online learning cannot be carried out if it is taken over directly by students' learning attitudes, so an analysis of the impact of online learning on student character is needed.

Inanna, (2018) stated that the character of the young generation today is increasingly worrying, not only leads to attitudes that move away from culture but has begun to lead to activities that can disrupt order in society and even the country. An increasingly worrisome character for the younger generation, integrated coaching is needed. Student character is formed through integrated processes in all activities carried out. Character is not formed in a moment but through a systematic program and has a precise measure (Manurung \& Rahmadi, 2017). Shaping the character of students is done in educational institutions because the most suitable place to train the formation of morals is with the assistance of teachers in educational institutions.

Character formation in student teachers is not enough to be limited to initial orientation, but programmed habituation is needed so that there is continuity during the lecture process. The character of students should be developed through activities that are integrated with learning. The use of a social scientific approach by integrating examples of

\footnotetext{
${ }^{*}$ Corresponding author.

Received 08 July 2020; Accepted 07 August 2020; Available online 1 September 2020 (c) 2020 JPI. All Rights Reserved
} 
scientific application in social life can develop attitudes and behaviour (Kurniawanti et al., 2020; Tanri et al., 2020; Yustina et al., 2020). Student activities that continuously and seriously train other forms of politeness, discipline, and responsibility can shape student characters (Susanti, 2013). The student character formation does not stop at attitude because it is expected to have a positive impact on efforts seriously. One way to strengthen character is by integrating teaching materials with local wisdom (Hartini et al., 2018; Nurjayanto \& Marzuki, 2018).

The habit of praying before and after learning becomes an important habit to initiate the integration of character values in learning. Khusniati, (2012) and Isti et al., (2018) stated that character could be instilled through various educational activities, including learning by using strategies that are closer to daily life. The selection of learning strategies in the form of methods, approaches, and learning models that have character-valued activities become an essential part that must be possessed by every lecturer. Integrating character through online learning must become a habit so that it takes commitment from each lecturer to facilitate this. Obstacles in learning during the pandemic are, of course, tremendous because the distance learning system requires the carrying capacity of the internet network and the mindset of lecturers and students.

Harzer, (2016) and Lavy, (2019) stated that there is an increase in learning interest when it is associated with strengthening character in learning because it encourages positive thinking about the study material. Positive ways of thinking about teaching materials and activities carried out on campus are essential to be formed with an approach to instilling character values. All students have the same opportunities as targets for character strengthening, but for students who still have the most strategic long study periods because they are expected to have an impact on the next generation of students. Student character formation through habituation can be achieved through lecture activities. It is following the findings of (Taufiqurrahman, 2018), activities to strengthen student character effectively carried out through lecture activities that integrate character in content and the delivery of material. The study results emphasize the importance of planting character values in the form of linking with lecture study material, as well as in the pattern of presentation of the material to form the students' daily habits. Nurgiyantoro \& Anwar, (2013) stated that presenting material that emphasizes contextual learning and using authentic assessment strategies have an impact on strengthening the character of students. The results of previous studies reinforce the importance of forming the character of students with positive habits that start from thinking and behaving in daily life.

Several rational reasons were found about the relationship between contextual learning and character. Contextual learning is known to have a holistic nature, learning by utilizing experience in the natural environment so that learning becomes meaningful (Gamaliel, S., 2018; Ibrahim, 2018; Warsito, S. et al., 2016). Character strengthening from the lecture process can be intensified in the form of service-learning so that the program will be more systematic and measurable (Handoyo, 2014; Safaruddin et al., 2020). Character is not just formed through the activity of learning but must be measured achievements for each individual. The constraints that exist in most character strengthening programs are still limited to action, not yet complete until the assessment of the character of each individual. The form of questionnaire assessment can be developed to measure the character so that the development of this program can be measured by the achievements and impacts caused (Diana et al., 2018; Hemafitria et al., 2014; Sanga, L. L. \& Elisa, 2012). After analyzing various previous findings, there is a huge concern in the online learning situation about character formation due to the full process of online learning. The preliminary study found that in face-to-face learning, student habituation still needs assistance and control.

Analysis of various research findings found that a character is not limited to just done through coaching, but coaching must continue to be measured to produce a character index so that the given treatment and the impact are measured. The purpose of the study is to measure the character index of mathematics and science student teachers in online learning during the COVID-19 pandemic. Character index is obtained from the measurement of the 
character of each target of the study. Measurements are made after online lectures are completed in one semester.

\section{Method}

The study uses mixed methods that refer to (Lederman \& Lederman, 2013). The mixed-methods stage begins with collecting and analyzing quantitative data through a questionnaire on the target students of Mathematics and Science student teachers at Universitas Negeri Semarang, followed by collecting and analyzing qualitative data through interviews and observations. Quantitative data were obtained using a closed questionnaire technique. The questionnaire was developed by adopting from (Staniszewska et al., 2015), which in its development began with identifying targets in the research objectives. The research targets were 340 student teachers who had filled out and returned the questionnaires. The sex of the respondents was 216 women and 124 men. Women dominated student teachers.

The five options Likert Scale is used to reveal the level of participant character. Option 5 choices with scoring provisions from the statement with the provisions of a score of 5 (very good), a score of 4 (good), a score of 3 (fair), a score of 2 (poor), and a score of 1 (very poor). Each score is obtained from the scoring rubric that has been developed following the criteria of each indicator. The data collection method is not only a questionnaire, although, in a COVID-19 pandemic situation, the data is also collected through interview instruments. After students complete their one-semester online lectures during a pandemic, online character index measurements are taken. The questionnaire consisted of 5 statements, carried out in-depth interviews to get complete information. The participant character index was obtained from measurements at the end of online lectures as a result of learning during the Covid-19 pandemic. Questionnaires were sent to each respondent via online links through WhatsApp groups. Interviews have been conducted on 50 respondents who have filled out the questionnaire, to 50 respondents obtained randomly to explore information on the results of the questionnaire.

The questionnaire instrument was first tested for validity to produce valid data. Data were analyzed using the SPSS program to determine the character categories of participants by categories; very good, good, fair, poor, and very poor. Determination of character categories by percentage analysis by dividing the score obtained divided by the total score. The five participant character indicators analyzed the validity of the questionnaire by calculating the mean and standard deviation. Descriptive analysis was conducted from the results of interview answers given by study participants.

\section{Results and Discussion}

The validity test of the student teacher character questionnaire instrument in online learning is presented in Table 1.

Table 1. Validity Test of Instrument

\begin{tabular}{|c|c|c|c|c|c|c|}
\hline & & $\begin{array}{l}\text { Pray at the } \\
\text { Beginning } \\
\text { of Lecture }\end{array}$ & $\begin{array}{l}\text { Present } \\
\text { on Time }\end{array}$ & $\begin{array}{c}\text { Polite } \\
\text { Language }\end{array}$ & $\begin{array}{c}\text { Submit } \\
\text { Assignment } \\
\text { on Time }\end{array}$ & $\begin{array}{l}\text { Pray at the } \\
\text { End of } \\
\text { Lecture }\end{array}$ \\
\hline $\mathrm{N}$ & Valid & 340 & 340 & 340 & 340 & 340 \\
\hline & Missing & 0 & 0 & 0 & 0 & 0 \\
\hline Mean & & 4,00 & 4,35 & 4,06 & 4,40 & 3,76 \\
\hline $\begin{array}{l}\text { Std. } \\
\text { Deviation }\end{array}$ & & ,925 & ,593 & ,745 & ,604 & 972 \\
\hline Sum & & 1360 & 1478 & 1379 & 1496 & 1278 \\
\hline
\end{tabular}

An instrument consisting of five-character indicators is declared valid, with a mean of 4.11, which means good. The results of this validity test become a reference for the five 
indicators of questionnaires that have been filled by 340 student teachers have been able to reveal the character that exists in the individual participants. Trend data for the five indicators are presented in Figure 1.

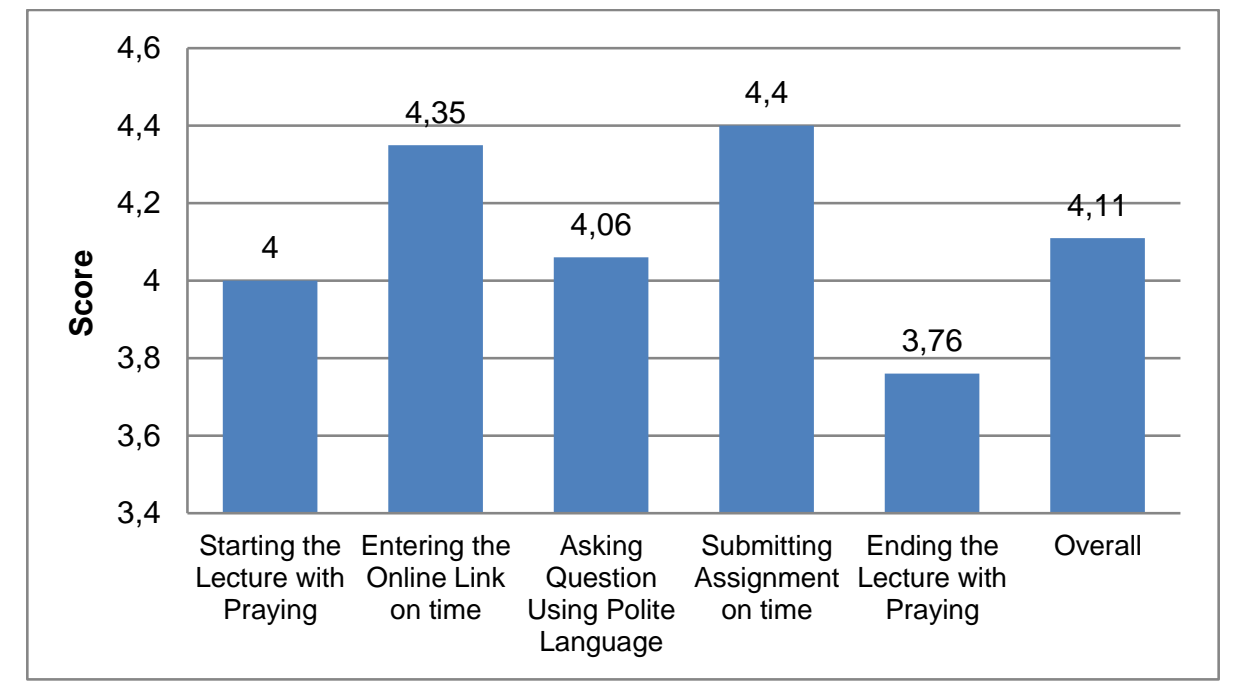

Figure 1. The score of Five Character Indicators of Mathematics and Sciences Student Teachers in Online Learning

The aspect of "submit an assignment on time" has a mean of 4.4 , the highest compared to the other four aspects. The aspect of "pray at the end of the lecture" has the lowest average compared to the four indicators. Overall, the average is 4.11 , which means good. Data from online interviews are presented in Table 2.

Table 2. Results of Online Interview

Start the lecture with praying

Enter the online link on time

Asking questions directly using polite language

Submitting assignments on time even in COVID-19 pandemic situations

Ending the lecture with praying

\section{Analysis of Respondent Answers}

Some students do not do so because they feel nervous about entering the online link provided. Feeling nervous because the signals are often unstable so forget to pray. Some also did not enter the online lecture group on time, so they did not join the prayer with classmates.

The unstable internet network constraint because some students live in villages is a significant factor for those who are late entering online links for the lecture.

Questions are partly submitted via chat because the opportunity to ask directly is limited, considering using limited applications such as zoom meetings and Google meet. Questions submitted via chat are abbreviated so that ethically is not good.

Online lecture assignments are given mostly through the Elena program and WhatsApp group but are collected mostly on time. There is even a feeling of shame when it is too late to be seen by fellow students online.

The number decreased compared to the beginning of the lecture because some experienced signal constraints and were interrupted before the praying carried out. 
From the characteristics of the research target of the interview results, an inhibiting factor is found due to technical obstacles. The identification of technical obstacles in this study is that online learning is not carried out with the same network quality standards so that the target of the study is that there are network constraints. The impact of disrupted network constraints is some of the character indicators measured in this study, such as prayer, there is still a small number who do not do so because of the unstable network due to interruption during the online lecture process.

\section{Discussion}

The COVID-19 pandemic situation is a crisis that has a profound impact on the educational process for mathematics and science student teachers. Both fields have scientific similarity, requiring a laboratory as a place of learning to test the truth of both sciences. Preparation of mathematics and science student teachers as a problematic learning situation in the middle of a pandemic is no longer face to face between students and lecturers. Learning is done online through the use of distance learning application programs. In any situation, student teachers are prepared to have scientific competence and have a character as future generations of educators. The student character has been observed and measured directly by seeing and meeting with students, but in a pandemic situation, both ways to find out the character development can no longer be done. The pandemic situation is thought to create psychological pressure because of the fear of the COVID-19 outbreak. Psychological disorders are compounded because there is a change in the way of learning from learning in the classroom and laboratory to distance learning. There are five indicators of character measurement obtained from this study which are simplified from the measurement of the character index that is usually done from 12 indicators. The pandemic situation needs to be simplified by measuring the students' character, not to increase the intense fear of a deadly virus outbreak. (Luh et al., 2020) stated that a pandemic situation is different from the usual situation in teaching and learning activities so that changes in the way of measuring various types of learning outcomes are needed. The findings of this study prove the differences with the character of the students found in the preliminary study. When studying online, students feel no need to make a habit of the attitude that has been done when learning offline. During online learning, students are free to dress, do not have to show their faces, and are not afraid to be late because the network can be used as an excuse.

The student character index from the indicator analysis of praying at the beginning and the end of the lecture experiences a difference. More people pray at the beginning than at the end of the lecture. From the results of the interview, this situation is caused by the impact of the unstable internet network. Praying becomes a habit led by the class leader, guided by lecturers in each subject. Most students join online learning from their hometown located in the countryside, so the quality of the network varies. When the lecturer asked to pray at the beginning, some students had not yet entered. At the end of the lecture, their network had been cut off, so they do not join the prayer. Praying has a significant impact on students' beliefs every time they start lectures so that it becomes an essential factor that can create a calmer learning atmosphere. (Santoso \& Okky, 2017) and (Pebrian et al., 2018) stated that praying before and after learning is one part of creating a calm learning atmosphere and arousing awareness and seriousness of learning. Online learning is hampered by unstable internet networks, which results in a decrease in the quality of prayer.

Attendance is an essential indicator of discipline. Students, as preservice teachers, in the online learning process, observed the timeliness of attending lectures. A character index of 4.35 means that most students attend the online lecture link on time, but because the signal is unstable, it results in and out of the link. Most of the student teachers, present on time, show that discipline is still high. There are a small number of students who are late entering, due to unstable internet network. The main obstacle is the internet network. If online learning will continue as a result of a pandemic, it has the potential to reduce student discipline. (Windhiyana, 2020) stated that internet network constraints become obstacles to the implementation of distance education. This finding, if not anticipated, could potentially 
lead to a decrease in the index of the character of mathematics and science student teachers.

The politeness of communication between students and students, students and lecturers decreased quality in online learning. Students prefer asking questions and giving opinions during discussions through the chat facility. The desire for practical and fast communication causes students to prefer chatting with abbreviated words. The message delivered is sometimes challenging to understand because some use slang words that the lecturer does not understand. This change in the way of direct online communication through chat decreases excellent and polite language attitudes. The politeness of the language becomes an essential part in shaping the character of student teachers. Need to find forms of character building respectful communication in online learning, if this is not done then, prospective educators may experience a crisis of language politeness due to online learning.

Interesting findings from this study are on the indicators of submitting assignments from lecturers. Embarrassment was revealed from the results of the interview because anyone who collected the assignment was late involved in the WhatsApp group and the online application used. This condition is even better compared to face-to-face learning because students who have not yet collected assignments may be unknown to other students. Online learning has a remarkable impact on students in collecting assignments. This achievement can be adopted for face-to-face learning. The presence of groups on social media has a positive impact because it causes embarrassment when it is too late to collect assignments. (Amaliah et al., 2020) stated that submitting assignments on time is one indicator of student character because it is a manifestation of each student's responsibility towards learning obligations.

Online learning still has the potential to continue for a long time in Indonesia because the pandemic situation due to the COVID-19 virus outbreak cannot be ascertained its expiration time. Online learning governance, which is oriented towards strengthening the character of students, should get serious attention and policy, especially in the education of student teachers. It is dangerous if a commitment to character building does not follow online learning. Lecturers do not meet face to face, so they cannot directly convey matters related to the development of attitudes and behaviour of student teachers. The readiness for conducting online lectures needs to be supported by regulations oriented to the preparation of comprehensive prospective educators. It is crucial to minimize the negative impacts caused by the formation of character. Each student teacher as an asset that will prepare future human resources, if it is not prepared with a strong character, it is feared to have an impact on the decline in the morality of future generations.

\section{Conclusion and Suggestions}

The four indicators of the character of mathematics and science student teachers in online learning are less than optimal. These four things consist of: starting and ending lectures with prayer, attendance, and politeness in language, while the optimal indicator on the timeliness of collecting assignments with an index of 4.40 from a maximum index of 5.00. If the impact of online learning during the COVID-19 pandemic lasts even longer, then it has the potential to reduce the student character index. This condition is very worrying about the preparation of preservice teachers. Regulations need to be prepared, at least in the form of habituation movements that are of a character value. The habituation movement can be done during the online process by way of habituation by the lecturer, using backdrop when online with identity with character, and inserting the message of the character clearly in each lecture.

\section{References}

Amaliah, L., Sari, S., \& Dida, F. (2020). Meningkatkan Kedisiplinan melalui Google Classroom dalam Mata Kuliah Bahasa Indonesia. Semantik, 9(1), 35-40. https://doi.org/DOI 10.22460/semantik.vXiX.XXX

Diana, L., Handoyo, \& Ika, Y. (2018). Development of Character Assessment Instruments in 
Service-Learning Biology Education Department Sanata Dharma University. International Journal of Indonesian Education and Teaching, 2(1), 71-79. https://doi.org/10.21831/jpv.v10i1.29564

Fukkink, R., Jilink, L., \& Kelder, R. (2019). The development of interaction skills in preservice teacher education: A mixed-methods study of Dutch preservice teachers. Early Childhood Education Journal, 47, 321-329. https://doi.org/10.1007/s10643-019-00927-7

Gamaliel, S., A. (2018). The Analysis of Scientific Attitude with Environmental Knowledge Through the Role Of Teacher And Parents (A Case Study of An Eco-friendly School in Salatiga). Jurnal Pendidikan Indonesia, 7(2), 130-136. https://doi.org/10.15294/jpii.v6i1.4851

Handoyo, L. D. (2014). Menumbuhkembangkan Karakter Mahasiswa melalui ServiceLearning Program di Mata Kuliah IImu Gizi dan Kesehatan. Jurnal Kependidikan Widya Dharma, 25(2), 183-200. https://doi.org/10.24071/ijiet.2018.020108

Hartini, S., Firdausi, S., Misbah, \& Sulaeman. (2018). The Development of Physics Teaching Materials Based on Local Wisdom to Train Saraba Kawa Characters. Jurnal Pendidikan IPA Indonesia, 7(2), 130-137. https://doi.org/10.15294/jpii.v7i2.14249

Harzer, C. (2016). The eudaimonics of human strengths: The relations between character strengths and well-being. In Vitters $\varnothing$, J. (Ed.) Handbook of Eudaimonic Well-Being (pp. 307-322). Springer International Publishing. https://doi.org/10.1007/978-3-319-424453_20

Hemafitria, Rohani, \& Fety, N. (2014). Pembinaan Karakter Mahasiswa melalui Organisasi Kemahasiswaan di STKIP-PGRI Pontianak. Jurnal Edukasi, 12(2), 205-216. http://dx.doi.org/10.31571/edukasi.v12i2.156

Ibrahim, H. (2018). Implementasi Strategi Pembelajaran Kontekstual dalam Pembentukan Karakter Peserta Didik di SMP Negeri 2 Pinrang. Jurnal Studi Pendidikan, 16(1), 73-84. https://doi.org/Doi.org/10.35905/alishlah.v16i1.735

Inanna. (2018). Peran Pendidikan Dalam Membangun Karakter Bangsa Yang Bermoral. Jurnal Ekonomi Dan Pendidikan, 1(1), 27-33. https://doi.org/ 10.26858/jekpend.v111.5057

Isti, N., Lise, C., \& Husamah. (2018). Implementasi Pendidikan Karakter dalam Pembelajaran IPA di SMPN XY Kota Malang. Jurnal Biotek, 16(1), 1-14. https://doi.org/10.24252/jb.v6i1.4243

Khusniati, M. (2012). Pendidikan Karakter melalui Pembelajaran IPA. Jurnal Pendidikan IPA Indonesia, 1(2), 204-210. https://doi.org/10.15294/jpii.v1i2.2140

Kurniawanti, Y., Saputro, B., \& Bahuguna, S. (2020). The Effectiveness of Development Results of Pro-show Media Based on Solar System Poem and Song on Student Learning Outcomes. Journal of Innovation in Educational and Cultural Research, 1(1), 1-6. https://doi.org/10.46843/jiecr.v1i1.1

Lavy, S. (2019). A Review of Character Strengths Interventions in Twenty-First-Century Schools: their Importance and How they can be Fostered. Applied Research Quality Life. https://doi.org/10.1007/s11482-018-9700-6

Lederman, N. G., \& Lederman, J. . (2013). Mixed Up About Mixed Methods. Journal of Science Teacher Education, 24, 1073-1076. https://doi.org/10.1007/s10972-013-9367-7

Luh, D., Nurhasanah, Maria, E., \& Heru, K. (2020). Pembelajaran pada Masa Pandemi Covid-19. Jurnal Teknologi Pendidikan, 22(1), 65-70. https://doi.org/10.21009/jtp.v22i1.15286

Manurung, M. M., \& Rahmadi. (2017). Identifikasi Faktor-faktor Pembentukan Karakter Mahasiswa. Jurnal Analisis Sistem Pendidikan Tinggi, 1(1), 41-46. 


\section{https://doi.org/10.36339/jaspt.v111.63}

Nurgiyantoro, B., \& Anwar, E. (2013). Prioritas Penentuan Nilai Pendidikan Karakter dalam Pembelajaran Sastra Remaja. Cakrawala Pendidikan, 3, 382-393. https://doi.org/10.21831/cp.v3i3.1626

Nurjayanto, P., \& Marzuki, M. (2018). Nilai-nilai Karakter pada Teknik Patri Tapal Kuda Lampu Andong di Kotagede Yogyakarta. Jurnal Pendidikan Karakter, 1(9), 133-151. https://doi.org/10.21831/jpk.v0i1.23588

Pebrian, R., Nurul, I., \& Susi, M. (2018). Spiritualitas, Doa dan Prestasi Belajar. Belajea: Jurnal Pendidikan Islam, 3(2), 125-140. http://dx.doi.org/10.29240/belajea.v3i2.652

Safaruddin, S., Ibrahim, N., Juhaeni, J., Harmilawati, H., \& Qadrianti, L. (2020). The Effect of Project-Based Learning Assisted by Electronic Media on Learning Motivation and Science Process Skills. Journal of Innovation in Educational and Cultural Research, 1(1), 22-29. https://doi.org/10.46843/jiecr.v1i1.5

Sanga, L. L., \& Elisa, N. (2012). Peran Organisasi Himpunan Mahasiswa Program Studi dalam Membentuk Karakter Kepemimpinan Calon Guru Kimia. Jurnal Pendidikan Kimia, 9(1), 259-264. https://doi.org/10.24114/jpkim.v9i1.6190

Santoso, B., \& Okky, P. (2017). Aplikasi Pembelajaran Doa Harian untuk Anak Usia Dini Berbasis Android. Jurnal Informatika Universitas Pamulang, 2(4), 220-228. http://dx.doi.org/10.32493/informatika.v2i4.1517

Staniszewska, A., Cotton, S., \& MacLennan, G. (2015). Modifying a validated instrument: the. Aberdeen Varicose Vein Questionnaire. Trials, 15, 56. https://doi.org/10.1186/17456215-16-S2-P56

Susanti, R. (2013). Penerapan Pendidikan Karakter di Kalangan Mahasiswa. Jurnal AlTa'lim, 1(6), 480-487. https://doi.org/10.15548/jt.v20i3.46

Tanri, J., Behrry, F. Z., Vandana, L., Winarno, I. M., \& Afiezan, A. (2020). Pengaruh Current Ratio, Net Profit Margin, Stabilitas Penjualan dan Struktur Aktiva terhadap Struktur

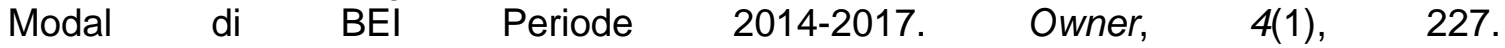
https://doi.org/10.33395/owner.v4i1.189

Taufiqurrahman. (2018). Pembentukan Karakter Mahasiswa dalam Sistem Pendidikan Tinggi Islam. Tadris, 13(1), 17-32. https://doi.org/10.19105/tjpi.v13i1.1716

Warsito, S., Asrowi, A., Mulyoto, M., \& Sri, A. (2016). The Effectiveness of IPS-based Contextual Learning to Improve Students Character. International Journal of Active Learning, 1(2), 56-65. https://doi.org/10.15294/ijal.v1i2.7740

Windhiyana, E. (2020). Dampak Covid-19 terhadap Kegiatan Pembelajaran Online di Sebuah Perguruan Tinggi Kriten di Indonesia. Perspektif IImu Pendidikan, 34(1), 1-8. https://doi.org/10.21009/PIP.341.1.

Yin, J. (2019). No TitleConnecting theory and practice in teacher education: English-as-aforeign-language preservice teachers' perceptions of practicum experience. Innovation and Education, 1(4). https://doi.org/10.1186/s42862-019-0003-z.

Yustina, Y., Halim, L., \& Mahadi, I. (2020). The Effect of "Fish Diversity" Book in Kampar District on the Learning Motivation and Obstacles of Kampar High School Students through Online Learning during the COVID-19 Period. Journal of Innovation in Educational and Cultural Research, 1(1), 7-14. https://doi.org/10.46843/jiecr.v1i1.2. 